\title{
SUSTAINABLE WATER RESOURCES MANAGEMENT AND POTENTIAL DEVELOPMENT OF MULTI-PURPOSE DAM: THE CASE OF MALAYSIA
}

\author{
LeE, K. E. $.^{*}-$ Shahabudin, S. M. ${ }^{2}-$ MoKhtAR, M. ${ }^{1}-$ ChOY, Y. K. ${ }^{3}-$ GoH, T. L. ${ }^{4}-$ SimOn, N. ${ }^{4}$ \\ ${ }^{1}$ Institute for Environment \& Development (LESTARI), Universiti Kebangsaan Malaysia \\ 43600 UKM Bangi, Selangor, Malaysia \\ ${ }^{2}$ National Water Services Commission, Aras bawah \& Aras 1, Prima Avenue 7, Blok 3510, \\ Jalan Teknokrat 6, 63000 Cyberjaya, Selangor, Malaysia \\ ${ }^{3}$ Graduate School of Economics, Kyoto University \\ Yoshida Honmachi, Sakyo-ku, Kyoto, 606-8501, Japan \\ ${ }^{4}$ School of Environmental and Natural Resources Sciences, Faculty of Science and Technology, \\ Universiti Kebangsaan Malaysia, 43600 UKM Bangi, Selangor, Malaysia \\ *Corresponding author \\ e-mail: khaiernlee@ukm.edu.my \\ (Received 21 ${ }^{\text {st }}$ Dec 2017; accepted 26 $6^{\text {th }}$ Mar 2018)
}

\begin{abstract}
As water scarcity increases globally due to rapid population growth, unsustainable use, water degradation and climate change, water security is increasingly becoming a serious and growing concern. Sustainable water resources management and development are central to addressing this pressing concern. One of the ways forward is through the development of multi-purpose dams. However, dam development is often mired with controversies over its environmental and social impacts. It is anticipated that multipurpose dam development is going to gain attention in Malaysia; the question at issue is not only about the multi-purpose dam development per se, but the sustainable water resources management. This article attempts to discuss water security issues in the Malaysian context, the needs for sustainable water resources management and environmentally sustainable multi-purpose dam development.
\end{abstract}

Keywords: water security, sustainable water resources management, multi-purpose dam, environment, social, economy, climate change

\section{Introduction}

By 2025 , it is projected that about 1.8 billion people will experience absolute water scarcity. Severe water stress affecting $1 / 3$ of the world's population is expected to double to $2 / 3$, and water withdrawals are predicted to increase by $50 \%$ in developing countries and $18 \%$ in developed countries. (BERNAMA, 2012).

Water scarcity may be defined as when the issue of water insecurity persists for a significant period of time, that is, when a large number of people in a region do not have access to safe and affordable water to satisfy their daily needs or livelihoods. Water security is defined as the capacity of a population to safeguard sustainable access to adequate quantities of acceptable quality water for sustaining livelihoods, human wellbeing, and socio-economic development. Many factors contribute to water security, ranging from biophysical and infrastructural, institutional, political, social, financial many of which lie outside the water realm. Addressing this goal therefore require interdisciplinary collaboration across sectors, communities and political borders. 
The American Society of Civil Engineers gives a holistic definition of sustainable water resources systems. Water resources systems should be designed and managed to fully contribute to the objectives of society, now and in the future, while maintaining their ecological, environmental, and hydrological integrity (Petersson and Ostrowski, 2003). Providing water for drinking and irrigation, producing hydropower and flood protection are by all means functions that contribute to the objectives of society. Water shortage will not be possible to solve without dams, although solving it only by means of dams will clearly not be preferable solution. Many collateral impacts of dams are running contradictory to society's objectives, or either the ecological or the economic integrity of the water resources system. To ensure the identification and implementation of widely accepted and sustainable solutions for water and energy development, it will be of major importance to implement well-structured and transparent planning processes for multi-purpose dam from the very beginning (Petersson and Ostrowski, 2003). This article attempts to discuss the current water security issues in the Malaysian context, the needs for sustainable water resources management and environmentally sustainable multi-purpose dam development.

\section{Water security issues: The Malaysian context}

Malaysia is a tropical country, having an average annual rainfall of $2400 \mathrm{~mm}$ and relatively rich in water resources. In the early decades of independence, Malaysia never experienced any serious water crisis. However, Malaysia is facing water shortage and having frequent water rationing nowadays, especially in Kuala Lumpur, Selangor and Putrajaya. The situation is exacerbated by the El Nino phenomenon which is anticipated to further worsen the water crisis in Malaysia (Raja Zainal Abidin, 2004). Such a paradox of plenty is due to the complexity of water security issues and must be sustainably addressed (Chan et al., 2003).

Over the past decades, Malaysia was lacking of a central agency entrusted with the overall responsibility of holistic planning and management of the overall aspects of water resources. There are too many agencies having jurisdiction over different aspects of water resources management either direct or indirectly. Table 1 shows the responsibilities of the Malaysian water related agencies.

Table 1. Malaysia's water related agencies

\begin{tabular}{c|c|c}
\hline Agency & Area of responsibility & Description \\
\hline $\begin{array}{c}\text { National Water Resources } \\
\text { Council (NWRC) }\end{array}$ & $\begin{array}{c}\text { Water resources matters - cross } \\
\text { boundaries/interstate/issues of national } \\
\text { interest }\end{array}$ & $\begin{array}{c}\text { Ensure coordination between various State } \\
\text { Governments in the management of river } \\
\text { basins }\end{array}$ \\
\hline $\begin{array}{c}\text { Ministry of Natural Resources } \\
\text { and Environment }\end{array}$ & Policy matters & $\begin{array}{c}\text { Formulates policies/guidelines/regulations } \\
\text { for the national water resources }\end{array}$ \\
\hline $\begin{array}{c}\text { Ministry of Energy, Green } \\
\text { Technology and Water } \\
\text { (KeTTHA) }\end{array}$ & Policy matters & $\begin{array}{c}\text { Formulates the policies and strategies for } \\
\text { national water supply and sanitation }\end{array}$ \\
\hline $\begin{array}{c}\text { Ministry of Finance }- \text { Water } \\
\text { Asset Management Inc, PAAB }\end{array}$ & Asset management & $\begin{array}{c}\text { Acquire and manage all state owned water } \\
\text { related assets }\end{array}$ \\
\hline $\begin{array}{c}\text { National Water Services } \\
\text { Commission (SPAN) }\end{array}$ & Regulatory matters & $\begin{array}{c}\text { Regulate water service industry (water and } \\
\text { sewerage services) }\end{array}$ \\
\hline $\begin{array}{c}\text { State and Territory } \\
\text { Governments (13 states and } \\
\text { three territories) }\end{array}$ & Raw water matters & $\begin{array}{c}\text { Regulates raw water abstraction and } \\
\text { catchment management }\end{array}$ \\
\hline
\end{tabular}


Conflicts in water resources management such as allocation of water rights, flood management, pollution control, environmental protection, etc are resolved through inter-agency coordination and consultation. Such a mechanism has led to sectoral management of water, conflicting/competing objectives and disputes between agencies.

Malaysia also suffers from a plethora of sector-based water laws, both at federal and state levels, and from the lack of a comprehensive water law. Table 2 shows legislations that relevant to Malaysian water resources management. All these legislations are contained within the laws that are enforced by the various water-related government agencies, and many of these laws are outdated, redundant or ambiguous and need to be reviewed in today's context. These diversified water legislations are also not comprehensive enough and do not deal directly with water issues, thus the government agencies are having difficulty to enforce effectively.

Table 2. Legislation that relevant to Malaysian water management

\begin{tabular}{|c|c|}
\hline Purpose & Laws and regulations \\
\hline Parliamentary acts & $\begin{array}{l}\text { - National Policies of Government of Malaysia - Third National } \\
\text { Agricultural Policy (1998-2010) } \\
\text { - Federal Constitutions } \\
\text { - Ministerial Functions Act } 1969 \text { (Perintah Menteri-Menteri } \\
\text { Persekutuan 2004): DID Role In On River Management in Flood } \\
\text { Mitigation and River Conservancy } \\
\text { - Water Act } 1920 \text { (Revised 1989) }\end{array}$ \\
\hline Land acts & $\begin{array}{l}\text { - National Land Code } 1965 \text { And Waters } \\
\text { - Land Conservation Act } 1960\end{array}$ \\
\hline Flood mitigation & $\begin{array}{l}\text { - Drainage Works Act } 1954 \text { (1988) } \\
\text { - Local Government Act (1976): (Peninsular) } \\
\text { - Earthworks Bylaws } \\
\text { - Street, Drainage and Building Act } 1974 \text { (1994) } \\
\text { - Town and Country Planning Act } 1976\end{array}$ \\
\hline River management & $\begin{array}{l}\text { - Waters Act } 1920 \text { (Act 418) \& Water Supply (Federal Territory of } \\
\text { Kuala Lumpur) Act } 1998 \text { (Act 581) } \\
\text { - Mining Enactment } 1962 \text { (F.M.S. Cap 147) } \\
\text { - Environmental Quality Act 1974 (Act 127) \& Subsidiary } \\
\text { Legislation } \\
\text { - Ministerial Functions Act } 1969 \text { (Act 2) } \\
\text { - National Forestry Act } 1984 \text { (Act 313) \& Wood-Based Industries } \\
\text { (State Legislatures Competency) Act 1984 (Act 314) } \\
\text { - Fisheries Act } 1985 \text { (Act 317) and Regulations } \\
\text { - Water Act } 1989 \text { - Chapter 15 } \\
\text { - Sewerage Services Act 1993 (Act 508) \& Regulations And Orders }\end{array}$ \\
\hline Hydrological \& water resources & $\begin{array}{l}\text { - } \quad \text { Drainage Works Act } 1954 \text { (1988) } \\
\text { - Waters Act } 1920 \text { (Cap 146) (1989) }\end{array}$ \\
\hline Urban stormwater & $\begin{array}{l}\text { - Street, Drainage and Building } 1974 \text { (Act 133) - Section 70A(9) } \\
\text { - Street, Drainage and Building } 1974 \text { (Act 133) - Section } 71\end{array}$ \\
\hline Agriculture drainage & $\begin{array}{l}\text { - Third National Agricultural Policy (1998-2010) } \\
\text { - Irrigation Areas Act } 1953 \text { (1989) } \\
\text { - Drainage Works Act } 1954(1988) \\
\text { - Waters Act } 1920 \text { (Cap 146) (1989) } \\
\text { - Fisheries Act } 1963 \text { (1985)/Inland Fisheries Act }\end{array}$ \\
\hline
\end{tabular}


Malaysia is still practising the traditional water management system which employs and depends heavily on the water supply management approaches - cater to demand. Table 3 shows the water production and consumption in Malaysia where production increases to cater the increasing water consumption. With the increasing demand and consumption, more water has to be produced and supplied. Thus, more structures like dams, water treatment plants and water distribution pipes need to be built. This approach is unsustainable in the long run as water demand may eventually surpass water supply. There are plans by the government to privatize water supply in almost every state. However, several water privatization schemes have not produced desirable results. The water privatization process is still lacking transparency and accountability. Unsuccessful privatization leads to unsustainable water management.

Table 3. Water production and consumption in Malaysia 2009-2012 (MLD)

\begin{tabular}{c|c|c|c|c}
\hline & $\mathbf{2 0 0 9}$ & $\mathbf{2 0 1 0}$ & $\mathbf{2 0 1 1}$ & $\mathbf{2 0 1 2}$ \\
\hline Production & 13,495 & 14,065 & 14,564 & 15,145 \\
\hline Consumption & 8,551 & 8,972 & 9,164 & 9,532 \\
\hline Buffer & 4,944 & 5,093 & 5,400 & 5,613 \\
\hline
\end{tabular}

The average water tariff of Malaysia is $0.39 \mathrm{USD} / \mathrm{m}^{3}$. Comparing to that of Indonesia $\left(0.77 \mathrm{USD} / \mathrm{m}^{3}\right)$ and Singapore $\left(1.88 \mathrm{USD} / \mathrm{m}^{3}\right)$, water tariffs in Malaysia can be deemed as one of the lowest in the world. Such a situation does not encourage water conservation but instead leads to water wastage and overuse of water, both of which undermine the sustainability of water. Table 4 shows the average urban water use (litre/capita/day) in Asian countries. Malaysian average urban water use (litre/capita/day) is 344, which is much higher than that recommended by UN (165) and other Asian countries, i.e. Japan, China, Singapore and Indonesia. Agriculture accounts for $68 \%$ of total water consumption in Malaysia. However, the irrigation efficiency is $50 \%$ at best in the larger irrigation schemes and less than $40 \%$ in the smaller ones. There is also no recycling of irrigated water being practised and these factors have contributed to high rate of water wastage.

Table 4. Average urban water use (litre/capita/day) in Asian countries

\begin{tabular}{c|c}
\hline Country & Average urban water use (litre/capita/day) \\
\hline Malaysia & 344 \\
\hline Japan & 314 \\
\hline China & 204 \\
\hline Singapore & 153 \\
\hline Indonesia & 130 \\
\hline
\end{tabular}

The national average of non-revenue water (NRW) is 36\% (36 1 loss out of every $100 \mathrm{l})$ which is way too high. Table 5 shows the NRW in all states in Malaysia 2013. The high level of NRW in Malaysia is caused by aged pipe network, poor maintenance of pipe network, illegal connections and absence of coherent implementation for active leakage control. It is estimated that $40 \%$ or $50,900 \mathrm{~km}$ of the pipe network was laid 40 to 60 years ago or longer. However, the lacking of funding for asset replacement and 
poor construction resulted in increasing leakage in the pipe network. Such a situation is further exacerbated by illegal connections which significantly contribute to commercial losses and revenue loss to the utilities. Thus, all these have now become the focus of regulatory oversight under the new licensing regime and areas to be improved (SPAN, 2012).

Table 5. Non-revenue water (NRW) in all states in Malaysia 2013 (SPAN, 2012)

\begin{tabular}{c|c|c|c|c}
\hline State & $\begin{array}{c}\text { System input } \\
\text { volume }\end{array}$ & $\begin{array}{c}\text { Billed authorized } \\
\text { consumption }\end{array}$ & NRW & NRW (\%) \\
\hline Johor & 1,580 & 1,163 & 417 & 26.4 \\
\hline Kedah & 1,326 & 651 & 675 & 50.9 \\
\hline Kelantan & 430 & 202 & 16 & 53.1 \\
\hline Labuan & 63 & 46 & 107 & 25.9 \\
\hline Melaka & 482 & 375 & 267 & 22.1 \\
\hline Negeri Sembilan & 734 & 468 & 180 & 36.3 \\
\hline Pulau Pinang & 988 & 809 & 561 & 18.2 \\
\hline Pahang & 1,065 & 504 & 365 & 52.7 \\
\hline Perak & 1,200 & 835 & 132 & 62.4 \\
\hline Perlis & 211 & 80 & 602 & 53.2 \\
\hline Sabah & 1,132 & 530 & 359 & 31.3 \\
\hline Sarawak & 1,150 & 790 & 1,575 & 34.5 \\
\hline Selangor & 4,564 & 2,989 & 210 & 33.8 \\
\hline Terengganu & 623 & 413 & 5,694 & 36.6 \\
\hline MALAYSIA & 15,549 & 9,855 & &
\end{tabular}

Climate change and water pollution issues also threaten the water security. The changing weather pattern is not adequately taken into account of the water resources planning. The weather and climate change, locally and globally, affect water resources in Malaysia. For example, El Nino phenomenon that occurred in 1997/98 has brought severe drought resulting in water crises in many parts of Malaysia. Many water catchments in Malaysia have yet to be gazetted and legally protected. Water catchments are exposed to incompatible development resulting in adverse environmental effects, which ultimately make water resources degraded and unsustainable. Water pollution reduces total water availability considerably as the increasing cost involved in treating polluted will not be economically viable and in some instances, polluted water are not treatable for consumption. Almost half of the rivers in Malaysia are getting polluted nowadays. There are 1,064 monitoring stations in Malaysia, out of this number, 619 $(58 \%)$ were found to be clean, $359(34 \%)$ were slightly polluted and $86(8 \%)$ were polluted (WEPA, 2006).

\section{Sustainable water resources management}

Without the conscious efforts in addressing water resources management issues, it would not able to safeguard quantity and quality of water for sustaining livelihoods, human well-being, and socio-economic development (Cosgrove and Rijsberman, 2000). 


\section{Robust water policy}

Efforts to develop, conserve, utilize and manage water resources have to be guided by a robust national water policy to ensure water resources in the country are managed sustainably and holistically. The re-structuring of water services industry which was initiated by the federal government has established a holistic water policy which covers not only water supply but also sewerage services to improve the efficiency of the water services sector for the benefit of the people as well as to maintain the sustainability of water resources. The national water policy is outlined in the National Policy Objectives for the Water Supply and Sewerage Services Industry. The policy aims to establish a transparent and integrated structure for water supply and sewerage services that delivers effective and efficient services to consumers. The policy provides a regulatory environment which facilitates financial self-sustainability amongst the operators in water services industry in the long term and an effective system accountability and governance between operators in water services industry. It also aims to regulate tariffs and ensure the provision of affordable water services on an equitable basis; the safety and security of water services systems and the long-term benefits of the consumers. The policy ensures long-term availability and sustainability of water supply including the conservation of water and contributes to the sustainability of watercourses and water catchments. The policy also facilitates the development of competition to promote economy and efficiency in water services industry and improve the quality of life and environment through the effective and efficient management of water services (PAAB, 2013). Also, the water policy should always keep up to the pace with climate change in view of climate change is also a challenging issue in managing water resources whereby the dynamic climatic condition could affect the availability and sustainability of water resources.

\section{Effective governance and institutional matters}

The government is primarily responsible for the planning, development and management of water resources projects in the country. As discussed in the previous section, there is no central agency entrusted with the overall responsibility of holistic planning and management of water to manage the overall aspects of water resources. To establish an effective governance structure for water resources in the country, it is necessary to recognize and understand the close relationship between land use and water resources management issues. The National Water Resources Council (NWRC) which was established in 1997 is a step forward towards integrated approach in managing water resources. Besides coordinating function and ensuring uniformity in policies, standards and priorities, being the forum where the federal and state governments link water and land strategy can be formulated resulting in optimal utilization and conservation of the nation's water resources, the NWRC should be provided with legal mandate to plan, coordinate and execute Integrated Water Resources Management (IWRM) in which it balances the conditions for sustainable development (national interest) and desirable socio-economic development (public interest) with ecological conditions (environmental integrity) (Azhar, 2000).

\section{Water economic efficiency}

Due to the increasing water shortage issues, water has become an economic good that has its own economic value. In Malaysia, government subsidies are common and 
tariff is practically very low because water is still regarded as a social good where the concept of full cost recovery is not observed because of sociopolitical considerations. In addition, the absence of established economic regulation complicates the problem. Increasing tariff to cost recovery levels often faced with resistance resulting water utilities are not able to comply with its service obligations. In view of the highly capitalintensive nature of the water service industry, more private investment is required to lighten the fiscal burden of the government. There is also a need to revise the tariffs which balance full cost recovery and consumer's ability to pay and it can be achieved if the capital investment cost can be kept as low as possible and the tariff set at an economic value. The tariff for domestic and non-domestic water supplies are expected to move towards those of developed nations whereby gradually tariff revision is needed to reflect closely the actual costs of developing water resources facilities. Also, to ensure the efficiency of the water services, specific actions need to be taken particularly in reducing leakages and non-revenue water. With the effective addressing non-revenue water issues and raising public awareness on water saving, hence the water resources can be conserved (Salleh, 2011).

\section{Sustainable water resources development}

In line with the increasing water demand, water resources development have to meet the rapid growth in population, industries, tourism and other economic activities. We also recognize the challenges in water shortage, rising water pollution and other environmental pressures. Hence, it is necessary to ensure sustainable water resources development. Integrated and holistic approaches which require engagement and close partnership between stakeholders, including federal and states governments, regulatory authorities, environmental agencies, health agencies, water service providers, contractors, land users, consumers, etc are needed especially in conducting a detailed environmental impact assessment prior to the initiation of new water resource development projects. In addition, the identified sites for dam development should be conserved and gazetted as water catchment areas to ensure project can be implemented as planned because there may not be any other suitable alternative sites available for dam construction (Salleh, 2011).

\section{Effective construction, operation and maintenance of water structures}

Apart from proper planning of water structures, safety is particularly concern in ensuring effective water structure construction, operation and maintenance. An InterDepartmental Committee on dam safety was established in May 1986 which consists of Drainage and Irrigation Department Malaysia, National Electricity Board, Penang Water Authority, Malacca Water Board, Muda Agricultural Development Authority, Sabah Electricity Board and Sarawak Electricity Supply Corporation under the stewardship of Public Works Department Malaysia. The committee has launched the Guidelines for Operation, Maintenance and Surveillance of Dams in October 1989 to provide specific procedures and practice to suit site and management conditions of individual dams. The guidelines are applicable to all dams (except tailings dams). The guideline not only prepares an operation and maintenance manual for the dam, it also stipulates the responsibilities for operation and maintenance activities, routine inspections as well as adequate instructions and arrangements for emergency actions. Continuous examination of the condition of a dam and its appurtenant structures and the 
review of operation, maintenance and monitoring procedures and results are needed in order to determine whether a hazardous trend is developing or appears likely to develop. These surveillance activities should be conducted throughout its active life by trained and competent personnel and the published guidelines should be diligently followed and reviewed periodically by the dam owners to ensure the sustainability of multi-purpose dam (Othman, 2006).

\section{Potentials of multi-purpose dam development in Malaysia}

International Commission on Large Dams defined large dam - more than $15 \mathrm{~m}$ in height, while including smaller dams up to $10 \mathrm{~m}$ height as well, if they are otherwise significant with respect to storage volume, density of population, etc. Dam is an artificial barrier together with appurtenant works constructed for the purpose of holding water or any other fluid or silt across a natural water course or on the periphery of reservoir to control the flow or the level of the water (DID, 2009). By proper altering the spatial and temporal distribution of runoff, dam could serve several functions (Zhou and Guo, 2013).

With the rapid economic development, the role of dam has become more and more important to meet society's water requirements as the dam is the cornerstone in the development and management of water resources of a river basin. The International Commission on Large Dams (ICOLD) has been promoting the theme of a water-foodenergy nexus and integrated solution whereby one problem cannot be solved without thinking of the other sides of the problem. This has highlighted the importance of multipurpose dams in resolving the issues of water, food and energy. However, most of the existing dams in the world are single-purpose dams (49.2\%). Among the single-purpose dams, $48 \%$ are for irrigation, $20 \%$ for hydropower (production of electricity), $13 \%$ for water supply, $9 \%$ for flood control, $5 \%$ for recreation and $5 \%$ for navigation, fish farming and others. ICOLD recorded only $16.8 \%$ of the worldwide dams can be categorized as multi-purpose dams where they are mostly built for irrigation purposes (24\%), followed by flood control (19\%), water supply (17\%), hydropower (16\%), recreation and navigation/fish farming (19\%) and others (5\%) (ICOLD, 2014). A multipurpose dam is gaining importance as it fits well into regional development programs, such as improving food production, electricity supply, and the general physical and social infrastructure in rural areas. In addition, multi-purpose dams can complement strategies for climate change adaptation. For example, hydropower generation can be combined with increased water storage or flood regulation.

To date, there are 65 major dams that have been developed in Malaysia. Table 6 shows the major dam development in Malaysia from 1950s to 2000s. Most of them were constructed for water supply. There were also dams built for hydropower, irrigation, flood mitigation, environmental and recreation purposes. Since 1980s, massive development has been devoted for water supply dams considering the increasing water demand due to population growth and country transformation from an agriculture-based economy into an emerging industrial manufacturing entity. It is noted that only 9 out of 65 dams in Malaysia serve more than one purpose in their function. Thus, it can be affirmed that the multi-purpose dam concept is still not very popular in the water resources planning and development of Malaysia. 
Table 6. List of dams in Malaysia

\begin{tabular}{|c|c|c|c|c|c|c|c|c|c|}
\hline No & Purpose & Before 1950s & 1950s & 1960s & 1970s & 1980s & 1990s & $2000 s$ & Total \\
\hline \multirow[t]{2}{*}{ A } & \multirow[t]{2}{*}{ 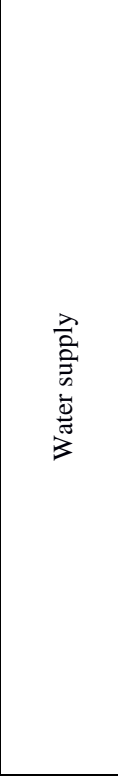 } & \begin{tabular}{|l|} 
Gunung Pulai \\
Scheme \\
(Johor) \\
1. Pulai I + II \\
dams \\
$2 . \quad$ Pontian \\
Kechil dam
\end{tabular} & 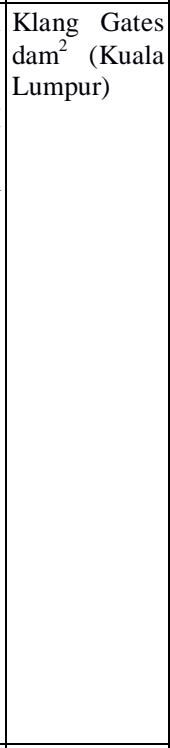 & \begin{tabular}{|l|} 
Air Hitam \\
dam \\
(Penang) \\
Congok dam \\
(Johor)
\end{tabular} & $\begin{array}{l}\text { Lebam dam } \\
\text { (Johor) } \\
\text { Durian } \\
\text { Tunggal dam } \\
\text { (Melaka) } \\
\text { Langat dam } \\
\text { (Selangor) } \\
\text { Pinangsoo } \\
\text { dam (Sabah) }\end{array}$ & \begin{tabular}{|ll} 
Semenyih & dam \\
(Selangor) \\
Terip & dam \\
(Negeri & \\
Sembilan) & \\
Malut & dam \\
(Kedah) & \\
Ahning & dam \\
(Kedah) & \\
Mengkuang \\
dam (Penang) \\
Layang Upper \\
dam (Johor) \\
Layang Lower \\
dam (Johor) \\
Timbangan \\
dam (Sabah) \\
Sikararar dam \\
(Sarawak) \\
Bukit r Kuda \\
(Labuan)
\end{tabular} & $\begin{array}{ll}\text { Sungai } & \text { Tinggi } \\
\text { dam (Selangor) } \\
\text { Linggiu dam } \\
\text { (Johor) } \\
\text { Air } \quad \text { Kuning } \\
\text { dam, (Perak) } \\
\text { Pedas } & \text { dam } \\
\text { (Negeri } & \\
\text { Sembilan) } & \\
\text { Juaseh } & \text { dam } \\
\text { (Negeri } & \\
\text { Sembilan) } \\
\text { Upper } & \text { Muar } \\
\text { dam (Negeri } \\
\text { Sembilan) } \\
\text { Gemencheh } \\
\text { dam, (Negeri } \\
\text { Sembilan) } \\
\text { Kelinchi dam } \\
\text { (Negeri } \\
\text { Sembilan) } \\
\text { Babagon } & \text { Dam } \\
\text { (Sabah) } & \\
\end{array}$ & \begin{tabular}{|ll|}
\multicolumn{3}{|l}{ Sungai } & Selangor \\
dam (Selangor) \\
Chereh & dam \\
(Pahang) & \\
Jus & dam \\
(Melaka) & \\
Betotan & dam \\
(Sabah) & \\
Milau & dam \\
(Sabah) & \\
Gerugu & dam, \\
(Sarawak) & \\
Labu & dam \\
(Selangor) & \\
Teluk & Bahang \\
dam (Penang) \\
Kelalang & dam \\
(Sarawak) & \\
Telibung & dam \\
(Sabah) & \\
\end{tabular} & \\
\hline & & 3 & 1 & 2 & 4 & 10 & 9 & 10 & 39 \\
\hline \multirow[t]{2}{*}{ B } & \multirow[t]{2}{*}{ 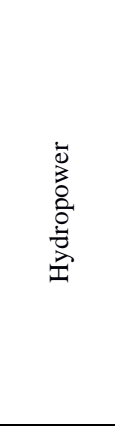 } & $\begin{array}{l}\text { Chenderoh } \\
\text { dam (Perak) }\end{array}$ & & \begin{tabular}{|l|} 
Cameron \\
Highland \\
Scheme \\
(Pahang) \\
1. Ringlet \\
Falls dam \\
$2 . \quad$ Batang \\
Padang \\
Scheme \\
Jor and \\
Mahang \\
(Perak)
\end{tabular} & $\begin{array}{l}\text { Temenggor } \\
\text { dam (Perak) }\end{array}$ & 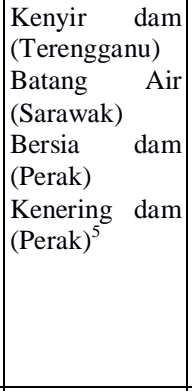 & $\mid \begin{array}{l}\text { Pergau dam } \\
(\text { Kelantan })^{5}\end{array}$ & $\begin{array}{ll}\text { Bakun } & \text { dam } \\
\text { (Sarawak) } & \end{array}$ & \\
\hline & & 1 & & 3 & 1 & 4 & 1 & 1 & 11 \\
\hline \multirow[t]{2}{*}{$\mathrm{C}$} & 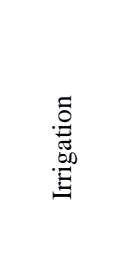 & 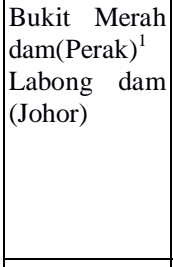 & & \begin{tabular}{|l|} 
Muda \\
Agricultural \\
Development \\
Authority \\
Scheme \\
(Kedah) \\
1. Pedu and \\
Muda dams \\
\end{tabular} & \begin{tabular}{|l|} 
Bukit Kwang \\
dam \\
(Kelantan)
\end{tabular} & \begin{tabular}{|lr} 
Anak & Endau \\
dam (Pahang) & 1 \\
Pontian & dam \\
(Pahang) & \\
Machap & dam \\
(Johor) &
\end{tabular} & $\mid \begin{array}{l}\text { Timah Tasoh } \\
\text { dam (Perlis) }\end{array}$ & $\begin{array}{ll}\text { Beris } & \text { dam } \\
(\text { Kedah }) & \end{array}$ & \\
\hline & & 2 & & 2 & 1 & 3 & 1 & 1 & 10 \\
\hline \multirow[t]{2}{*}{$\mathrm{D}$} & \multirow[t]{2}{*}{ 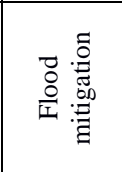 } & & & & & \begin{tabular}{|l|} 
Sg Batu dam \\
(Selangor) $^{4}$ \\
Sembrong dam \\
(Johor)
\end{tabular} & $\begin{array}{ll}\text { Bekok } \\
(\text { Johor })^{4}\end{array}$ & & \\
\hline & & & & & & 2 & 1 & & 3 \\
\hline \multirow[t]{2}{*}{$\mathrm{E}$} & \multirow{2}{*}{ 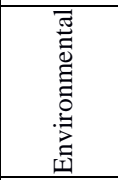 } & & & \begin{tabular}{|l|} 
Silt retention \\
Repas baru \\
dam, \\
(Pahang)
\end{tabular} & & & & & \\
\hline & & & & 1 & & & & & 1 \\
\hline \multirow[t]{2}{*}{$\mathrm{F}$} & \multirow{2}{*}{ 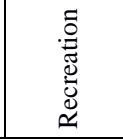 } & & & & & & & $\begin{array}{l}\text { Putrajaya dam, } \\
\text { (Wilayah } \\
\text { Persekutuan) }\end{array}$ & \\
\hline & & & & & & & & 1 & 1 \\
\hline & Total & 6 & 1 & 8 & 6 & 19 & 12 & 13 & 65 \\
\hline
\end{tabular}

Large dams defined as $>15 \mathrm{~m}$ and/or storage volume $>3$ million $\mathrm{m}^{3}$

${ }^{1}$ Water supply/irrigation

${ }^{2}$ Water supply/flood mitigation

${ }^{3}$ Water supply/irrigation/flood mitigation

${ }^{4}$ Flood mitigation/water supply

${ }^{5}$ Hydropower/flood mitigation 
The growing of water demand requires either better water supply management or additional supplies. Dam management plays a vital role in ensuring equitable water supplies. The management of dams in Malaysia is divided into four groups, i.e. flood mitigation, hydroelectric, water supply and agriculture as shown in Table 7. Generally, the water supply dams in Malaysia are managed and operated by private and water board of respective states. Drainage \& Irrigation Department (DID) is presently managing 15 dams within Malaysia and providing adequate irrigation water, flood mitigation and silt retention. More dams are scheduled for implementation in the future to meet the ever increasing demands and social expectations of the public. Tenaga Nasional Berhad, the main Malaysian energy provider, is operating 3 hydroelectric schemes in the peninsular Malaysia with an installed generating capacity of 1,911 MW. They are the Sungai Perak, Terengganu and Cameron Highlands hydroelectric schemes with 21 dams in operation. Despite having most of the dams for water supply purpose, Malaysia is still facing water shortage crisis. Water supply is relatively unstable in some parts of the country, particularly in Klang Valley. The development and population growth is occurring at a robust pace, and even now the residents are starting to experience water shortage and water rationing, which can be more acute in the next decade. Syarikat Bekalan Air Selangor Sdn Bhd (SYABAS) had issued a warning that the Klang Valley will face a water crisis unless the authorities implement three water resource projects by 2014. The projects are the Sungai Langat 2 water treatment plant, the Pahang-Selangor raw water tunnel and the Salak Tinggi dam projects, which have not taken off so far because of the differences between the federal and state government, particularly over land acquisition and water price (Bedi and Avineshwaran, 2013). According to SYABAS, these three water resource projects must be expedited to meet the rising demand for water supply in Selangor, Kuala Lumpur and Putrajaya, which is growing by $3.5 \%$ yearly. Such a situation has triggered the need to investigate the feasibility of multi-purpose dam development in Malaysia. With the increasing water demand in Malaysia, multi-purpose dam is likely to become relevant in ensuring equitable water demand management. The multi-purpose dam is not only accelerating socio-economic growth but also mitigating the miseries of the population from suffering of the vagaries of floods and droughts.

Table 7. Dams management in Malaysia (as of 2006)

\begin{tabular}{c|c|c}
\hline No & Purpose & Dam operator \\
\hline 1 & Water supply & Private \& Water Board \\
\hline 2 & Flood mitigation/environment & Drainage \& Irrigation Department \\
\hline 3 & Hydroelectric & Tenaga National Berhad \\
\hline 4 & Agriculture & Others \\
\hline
\end{tabular}

\section{Aspects to be considered in developing multi-purpose dam}

There are generally five interconnected aspects, namely legal, technical, economic, social and environment in developing a dam. These aspects need to be considered in the planning, funding, constructing, operating and maintaining of a multi-purpose dam to ensure the sustainability of water resources. 


\section{Legal aspects}

\section{Existing legal framework and institutional matters}

Legal and regulatory issue is one of the areas concerned in managing water resources. However, there is no specific act available for dam development and management, particularly multi-purpose dam in Malaysia. The only dam development relevant legal requirements are shown in Table 8 which are covered under Environmental Quality (Prescribed Activities) (Environmental Impact Assessment) Order 1987 for the construction of dams of drainage and irrigation, power generation and transmission as well as water supply (CIDB, 2008).

Table 8. Environmental Quality (Prescribed Activities) (Environmental Impact Assessment) Order 1987 for dam construction

\begin{tabular}{c|l|l}
\hline \multicolumn{1}{c|}{ Schedule } & \multicolumn{2}{|c}{ Activities } \\
\hline 3 (a) & Drainage and irrigation & $\begin{array}{l}\text { Construction of dams and man-made lakes and } \\
\text { artificial enlargement of lakes with surface areas of } \\
200 \text { ha or more }\end{array}$ \\
\hline 13 (b) & $\begin{array}{l}\text { Pams and hydro-electric power schemes with either or } \\
\text { both of the following: } \\
\text { (i) Dams over 15 m high and ancillary structures } \\
\text { transmission }\end{array}$ & $\begin{array}{l}\text { covering a total area in excess of 40 ha } \\
\text { (ii) Reservoirs with a surface area in excess of 400 ha }\end{array}$ \\
\hline 19 (a) & Water supply & \\
\hline
\end{tabular}

Taking other countries as benchmark, Japan enacted "Specified Multipurpose Dam Law" in 1957 to centralize the construction and administration of dams under the control of river administrators (Musiake and Koike, 2009) and South Korea enacted "Specific Multi-Purpose Dam Law" in 1966 to address various issues including financing of the construction of dams, support for flood victims, rational use and development of water resources to promote economic development and enhance the quality of life (Ministry of Strategy and Finance, Republic of Korea (2013). An adequate legal planning in the construction of multi-purpose dam is necessary. In 19661975, the South Korea's government has established master plans to construct multipurpose dams for water supply and control. After 1990's, the scope of multi-purpose dams was expanded to cover water supply, water control, and environmental preservation (Moon and Kwon, 2003). Under Water Resources Bureau of Ministry of Construction and Transportation, the entities namely Water Resources Policy Team and Water Resources Development Team are responsible to dam related policy making, research and development, dam related public relation, dam related National Assembly matters and budget, operation of dam related acts and system improvement, handling of property rights of dams and water facilities, planning and coordination, budget and setting and supervision of multi-purpose dam construction. However, in the Malaysia's context, as mentioned earlier, the government is still practicing the traditional water resources management system which employs and depends heavily on the water supply management approaches - cater to demand. Besides, Malaysia is also lacking a regulatory framework to govern the development and management of dam, particularly multi-purpose dam, as compared to other advanced countries. 
Prior to 2005, water supply was under the purview of respective state government. The state governments mostly own the water infrastructures and operate the water services. There are also some states, such as Selangor and Johor, where the water services are privatized and responsible for the treating and supplying of water to consumers. Therefore, institutional issues such as the water industry were not centrally regulated, causing inconsistency in service delivery. The varying degree of quality of water supply and services, different rules, procedures, key performance indexes (KPIs) and level of services, non-uniform in legislation and tariff setting principles have become challenges for the development of water industry. In the states where water services are privatized, operations are fragmented with several private operators involved in providing water supply to the states which is highly inefficient (PAAB, 2013). The federal government takes the initiative to reform the industry for the benefits of all stakeholders including federal government, state governments and consumers in the early of 2003. It was an extensive process which included amendments to the constitution and passing of new legislations to enable the government to mobilize the reformation. An amendment to federal constitution pertaining to jurisdiction on water supply was gazetted on 10 February 2005 whereby water services and supplies are listed under concurrent list between state governments and federal government. The amendment to the ninth schedule involves the transfer of water supplies and services from the state list to the concurrent list whereby the water supplies and services are shared responsibility between the state and the federal governments. It was a pertinent move which gave the federal government authority over the water services in the states. The tenth schedule was also amended. The revenue from water supplies and services (previously assigned to the states) is now under the federal government. Figure 1 shows the water governance before and after the federal constitution amendment in 2005.

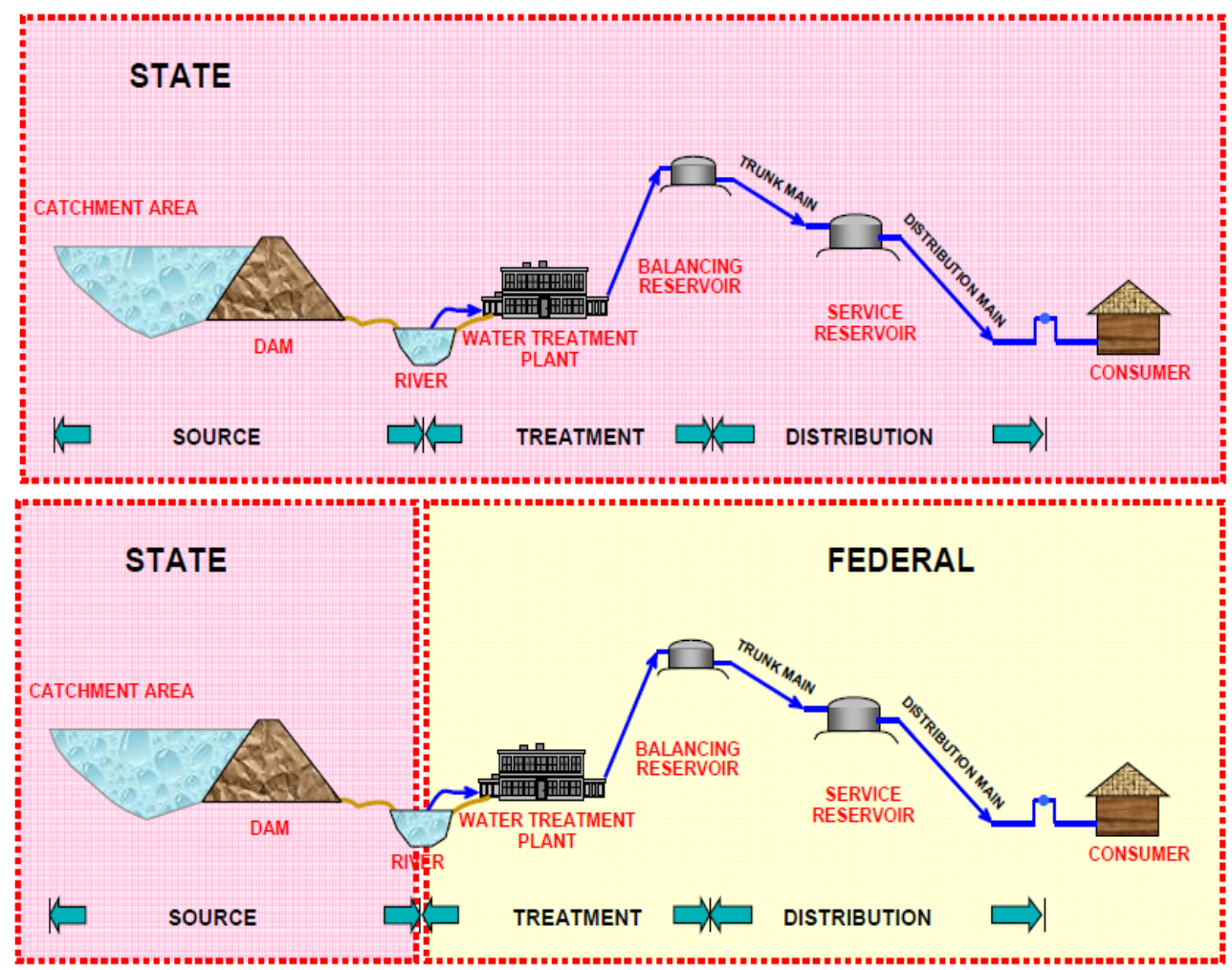

Figure 1. Water governance after federal constitution amendment in 2005 (Wahab, 2011) 
With effect from 21 March 2005, the federal government holds the right in regulating water treatment, distribution until the delivery to consumer whereas the ownership and control of rivers, canals, dam and water catchment remains under the state governments. The state governments retain the power to declare and regulate water catchment areas, water sources and river basins (Wahab, 2011). Figure 2 shows the roadmap of acts amendments. Further amendments were carried out in July 2006 whereby parliament passed two new legislations namely the National Water Services Commission Act 2006 and Water Service Industry Act 2006 (WSIA). Table 9 shows the policy and institutional framework on water services reform. National Water Services Commission Act provides for the establishment of National Water Services Commission (SPAN) as the technical and economic regulator and set out the function and power of SPAN. Water Service Industry Act provides the legal framework required for the regulation of the water and sewerage service industry. The Acts were enforced on $1^{\text {st }}$ February 2007 and $1^{\text {st }}$ January 2008 , respectively.

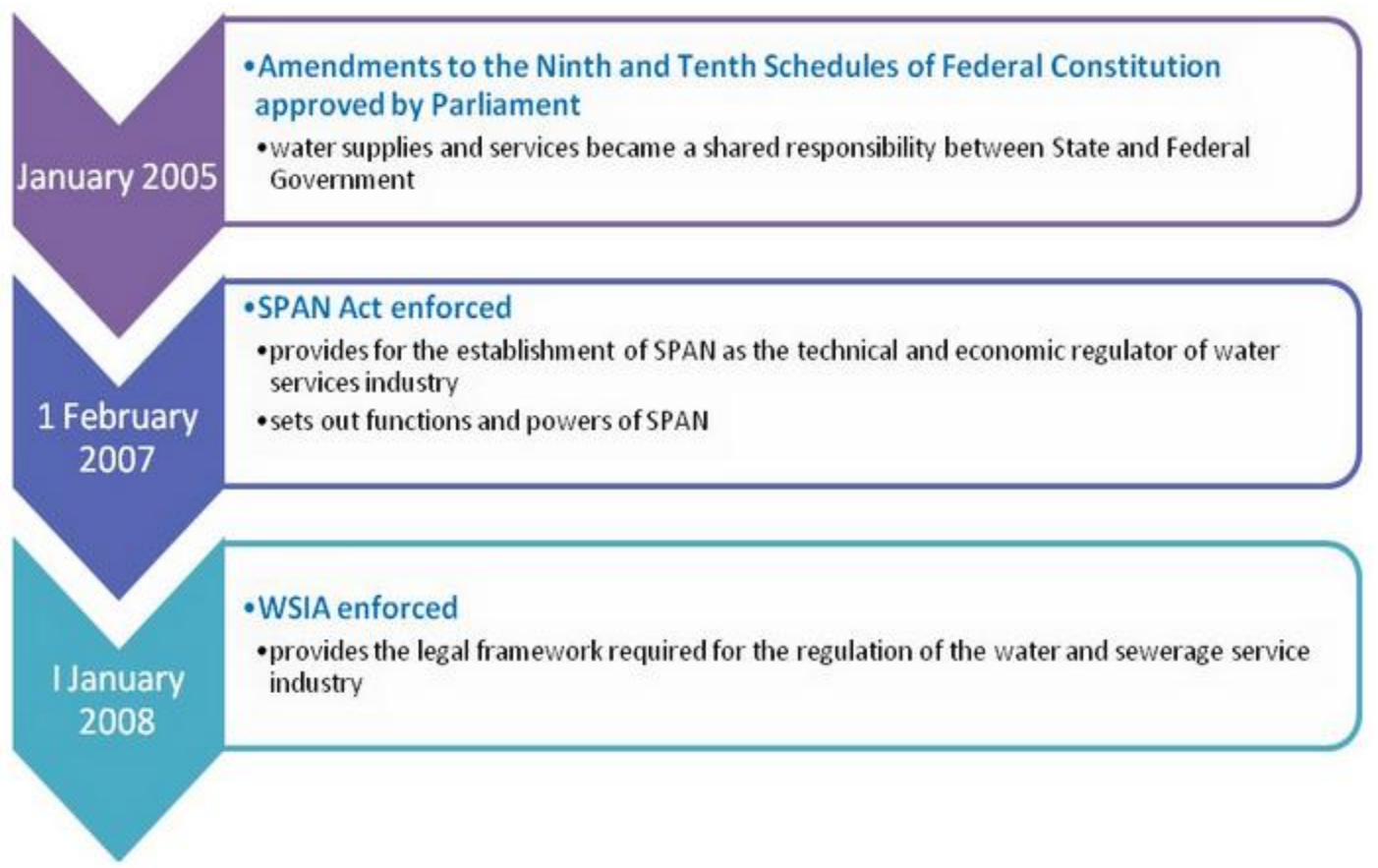

Figure 2. Roadmap of water services acts amendments (PAAB, 2013)

Table 9. Policy and institutional framework on water services reform (Wahab, 2011)

\begin{tabular}{c|c|c}
\hline Body & Area of responsibility & Description \\
\hline Federal Government & Policy matters & $\begin{array}{c}\text { Development of a holistic water } \\
\text { policy for the country by setting } \\
\text { policy directions }\end{array}$ \\
\hline $\begin{array}{c}\text { National Water Resource Council } \\
\text { (NWRC) - chaired by Prime } \\
\text { Minister }\end{array}$ & $\begin{array}{c}\text { Water resources matters - cross } \\
\text { boundaries/inter state/issue of } \\
\text { national interest }\end{array}$ & $\begin{array}{c}\text { Regulate raw water abstraction } \\
\text { and catchment management }\end{array}$ \\
\hline $\begin{array}{c}\text { Ensures coordination with the } \\
\text { various State Governments in the } \\
\text { management of the water basins } \\
\text { Commission (SPAN) }\end{array}$ & $\begin{array}{c}\text { Regulate the Water Services } \\
\text { industry (Water and Sewerage } \\
\text { services) }\end{array}$ \\
\hline
\end{tabular}




\section{Impact assessments and monitoring}

Under Environmental Quality (Prescribed Activities) (Environmental Impact Assessment) Order 1987, the construction of dams requires obtaining the following approvals from the Director-General of Department of Environment prior to project commencement:

i. Environmental impact assessment for prescribed activities

ii. Site suitability evaluation

iii. Written notification or permission to construct

iv. Written approval for installation of equipment

v. License to occupy and operate prescribed premises and prescribed conveyances

However, the schedules only cover drainage and irrigation; power generation and transmission and water supply. There is no specific schedule for multi-purpose dam construction. Considering constructing a multi-purpose dam is a complex process as it needs to take into account of the challenges of social, environment and its sustainability and it would be a challenge for the proposal to construct a multi-purpose dam.

Constructing a dam represents a potential water resource which is tantamount to potential hazard to downstream life, property and natural resources. Failure of any type of dam structure can result in loss of life, property and natural resources. Thus, a dam structure needs to be planned, constructed, and kept under proper surveillance, maintained to keep them in safe serviceable condition. A manual on Dam Safety, Inspection and Monitoring has been developed by Department of Irrigation and Drainage (DID) of Malaysia specifies the dam safety, inspections and monitoring throughout the lifecycle of the dam. Figure 3 shows the lifecycle of a dam where it starts from planning, design, construction, commissioning, reservoir filling, operation, maintenance and surveillance to abandonment or rehabilitation. Each stages, the roles of government and consultants in monitoring the lifecycle of the dam is shown in Table 10 (DID, 2009).

\section{Lawsuits and dispute settlement}

Lawsuits and dispute settlement is another legal and regulatory aspect to be taken into account in constructing a multi-purpose dam, particularly over environmental impact assessments (EIA) and community relocation. According to Sovacool and Bulan (2011), critiques related to reliance EIA on inadequate data, poor or incomplete hydrological analysis, and predictions of sediment delivery incorrect by more than one order of magnitude, as well as flawed projections about the effect on biodiversity and displaced communities have led to lawsuits filed against the dam construction projects in Malaysia. Non-governmental organization (NGOs) banded together to oppose dam construction projects, where they argued that consultation with the displaced communities was prone to multiple errors related to surveys of land, compensation, choice of contractors and consultants for the site, and the logistics of the relocation itself. The ineffective executions of the environmental and social impact assessment for the dam construction planning have resulted dispute and questioned on the legitimacy of parts of EIAs.

In South Korea, the "Act on Dam Construction and Assistance, Etc. To Neighbourhood Area" has been enforced in $10^{\text {th }}$ Dec 2009 to give a guideline for construction, management of dams and support for residents of dam construction area. 


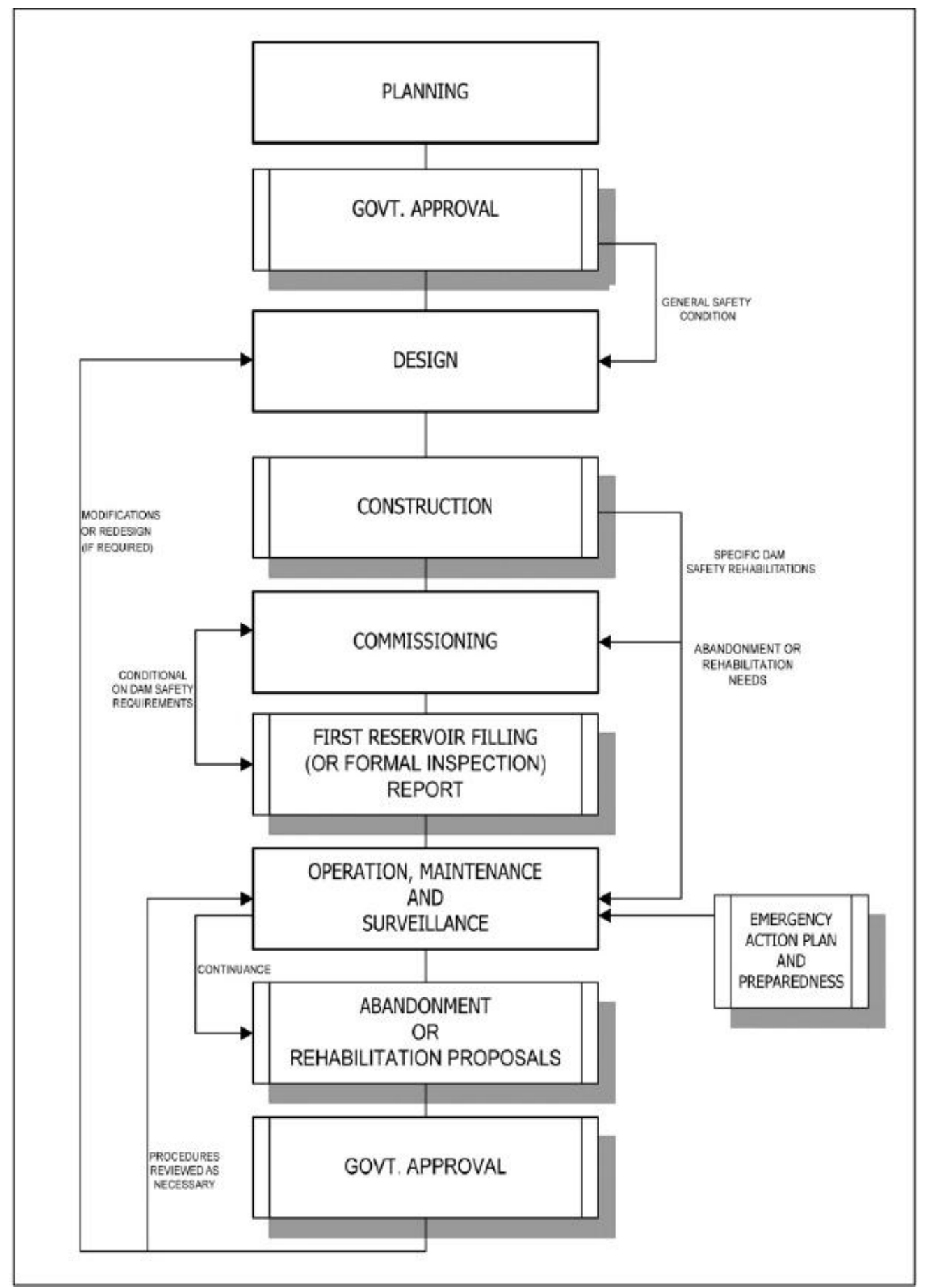

Figure 3. Lifecycle of a dam (DID, 2009)

The purpose of the Act is to contribute to the development of the national economy through the rational development and utilization of water resources by providing for the construction and management of dams, the reuse of construction costs, environment countermeasures according to the construction of dams and assistance to the residents of areas adjacent to dams (Ministry of Land, Transport and Maritime Affairs Korea 2009). Malaysia is still lacking an Act to be enacted specifically for dam development and management which is able to provide a guideline for developing environmentally and 
sustainable sound dams. In the Act, a holistic dam planning, development and management mechanism should be expounded where a pre-survey, social and environmental impact assessment shall be carried out effectively together with the local residents' councils and civil organization to avoid dispute and ensure construction of dams in harmony with local environment and communities.

Table 10. Roles of government and consultants in dam's life cycle (DID, 2009)

\begin{tabular}{|c|c|c|c|}
\hline Stage & Activity & Role of government/DID & Consultants \\
\hline \multirow[b]{3}{*}{ Planning } & - Concept & $\begin{array}{ll}\text { - } & \text { Ascertain need } \\
\text { - } & \text { Reconnaissance }\end{array}$ & \\
\hline & - Prefeasibility study & \begin{tabular}{|ll} 
- & Prepare \\
proposals & TOR/Invite \\
- & Appoint \\
consultants/Finance
\end{tabular} & $\begin{array}{l}\text { - Carry out investigations } \\
\text { and prepare report }\end{array}$ \\
\hline & - Feasibility study & 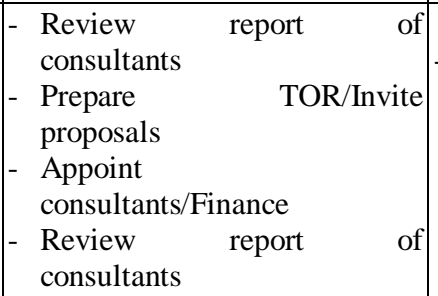 & $\begin{array}{l}\text { - Carry out investigations } \\
\text { and prepare report, } \\
\text { including EIA, EMP and } \\
\text { socio-economic study of } \\
\text { the people affected by } \\
\text { the project }\end{array}$ \\
\hline Design & - Detailed design & 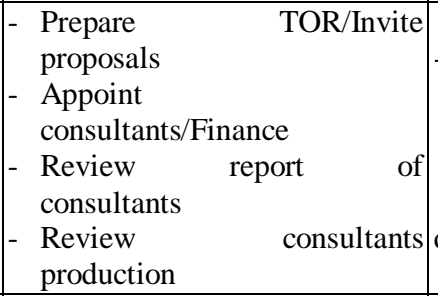 & 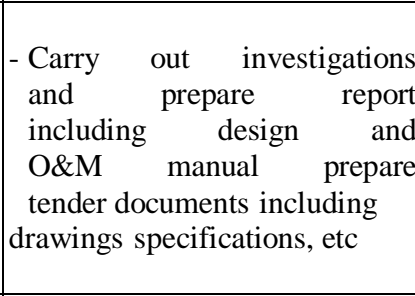 \\
\hline \multirow[b]{2}{*}{ Construction } & - Tendering & - Prequalify/Call for tenders & $\begin{array}{l}\text { - Prepare criteria/NIT } \\
\text { - Assist government/DID in } \\
\text { evaluation }\end{array}$ \\
\hline & - Construction & $\begin{array}{l}\text { - Evaluate tenders/Award } \\
\text { - Supervise construction, } \\
\text { executed by constructors } \\
\text { - Make payment to the } \\
\text { contractors as per contracts }\end{array}$ & $\begin{array}{l}\text { - Assist DID in supervision } \\
\text { of construction of works, } \\
\text { including evaluation of } \\
\text { the work executed, } \\
\text { preparation of payment to } \\
\text { the contractor and } \\
\text { evaluation of contractual } \\
\text { claims, if any }\end{array}$ \\
\hline \multirow[b]{2}{*}{$\begin{array}{l}\text { First reservoir } \\
\text { filling }\end{array}$} & \multirow[b]{2}{*}{ - Vigilance } & $\begin{array}{ll}\text { - } & \text { Exercise vigilance till } \\
\text { reservoir is full, and after }\end{array}$ & $\begin{array}{l}\text { - Assist government/DID in } \\
\text { exercising vigilance }\end{array}$ \\
\hline & & $\begin{array}{|lrr|} & & \\
\text { To keep } & \text { liaison } & \text { with } \\
\text { relevant authorities } & \text { for } \\
\text { emergency preparedness } & \end{array}$ & $\begin{array}{lll}\text { - Prepare } & \text { First } & \text { Reservoir } \\
\text { Filling Report, including } & \text { ing } \\
\text { inspection and monitoring } \\
\text { and assessment } \\
\text { dam's performance }\end{array}$ \\
\hline $\begin{array}{l}\text { Operation and } \\
\text { maintenance }\end{array}$ & $\begin{array}{l}\text { - Surveillance } \\
\text { - Monitoring } \\
\text { - Inspection } \\
\text { - Operation } \\
\text { - Maintenance } \\
\end{array}$ & $\begin{array}{ll}\text { - } & \text { Execute } \\
\text { - } & \text { Execute } \\
\text { - } & \text { Execute } \\
\text { - } & \text { Execute } \\
\end{array}$ & \\
\hline Aging & - Rehabilitation & 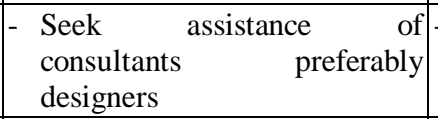 & \begin{tabular}{|l} 
- \\
Design and supervise \\
$\begin{array}{l}\text { construction executed by } \\
\text { contractors }\end{array}$
\end{tabular} \\
\hline Abandoning & - Decommissioning & $\begin{array}{|lrr|}\text { Execute, get } & \text { structures } \\
\begin{array}{l}\text { dismantled } \\
\text { required }\end{array} & \text { as } & \text { and if } \\
\end{array}$ & $\begin{array}{l}\text { - Advise/Design dismantling, } \\
\text { if required }\end{array}$ \\
\hline
\end{tabular}




\section{Technical aspects}

\section{Hydrology, rainfall and sedimentation}

The complexity in planning, constructing, operating and maintaining of multipurpose dams is a major challenge in its realization. These activities involve sophisticated technical requirements. In the planning and constructing of a multipurpose dam, hydrology of the water catchment is one of the main challenges to be overcome. The dam should be designed to cater the rainfall volume. Learning from the experience of Bakun (Sovacool and Bulan, 2011) whereby Bakun area was prone to lots of rainfall, more than $4500 \mathrm{~mm}$ per year in some years. Building a dam in that type of weather proved difficult. The underestimation of the rainfall has caused unsuitable design and led to the redesign of Bakun dam. Such a flawed dam design has caused a big lost to the investment. In addition, sedimentation is also a challenge, in which logging, land clearing and unsustainable agricultural practices have caused the severe deforestation. High rainfall will cause the runoff of large amounts of sediment, silt, clay and gravel into the water body. Such a high sedimentation rate may impede the dam construction, operation and maintenance whereby extra technical considerations need to be taken into account to avoid damage to the dam.

\section{Geographical isolation and provision of infrastructure}

Due to the geographical and hydrological needs, the location of the dam construction is usually planned in an isolated area whereby no access roads and other infrastructure around the construction site. Transporting the construction materials, turbine and transformer components to the dam site is a challenge as the items are way too heavy to be transported. Therefore, a massive infrastructure development from scratch is required to take place to bring in construction materials and generators. Despite the said necessity for the dam construction, there are also needs to supply accommodation, medical service, food, clean water, electricity to the construction staffs before construction could commence. In other words, building a dam is not solely concerning about the reservoir only, but it needs a holistic planning for the adjacent development to ensure the sustainability of a dam (Sovacool and Bulan, 2011).

\section{Dam excavation, construction, coordination and human resources}

In addition to the provision of infrastructure, the dam excavation and construction are of the main technical challenges whereby each dam needs river diversion, tunnelling, channelling and access to the dam to transport machines and turbines (Sovacool and Bulan, 2012). The complexity of the project hence required coordination and human resources for the excavation and construction. Over thousands of skilled workers, engineers and contractors are needed in the construction of dam in building spillways, powerhouses, transformers, turbines, and the dam face. In developing country like Malaysia, there is lack of technical capacity to build dam, hence thousands of foreign workers need to be imported to participate in the dam construction. Besides that, building a dam also needs joint venture with many sub-contractors in which the selection of the competent sub-contractors is particularly important. The coordination of these workers and sub-contractors is formidable because any flaw in coordination will cause a major disaster to the project. 


\section{Infrastructure operation and maintenance}

The challenge of operating a multi-purpose dam is the balancing of competing demands. For example, the water level often needs to be as high as possible in view of the stored water in the dam serves as the stored energy for hydroelectric power generation purpose. However, for flood control purpose, the water level needs to be as low as possible to provide the storage space for rainwater runoff. Operators need to release enough water for downstream navigation, but store enough water to have a safety margin for electricity generation. River flow in a tropical rainfall country can rise as much as $10 \mathrm{~m}$ per day, $20 \mathrm{~m}$ when raining or flooding (Sovacool and Bulan, 2011). Such a contrast makes the operation of multi-purpose dam critical and challenging in the management of water level, mismanagement and misoperation might cause catastrophic damage in the downstream area with a clean sweep of the life and property that comes in its way. For instance, a tragedy happened in Cameron Highlands in 2013, whereby at least three people are dead and dozens of houses and cars were damaged after flood water was released from the dam. The operator claimed that the water was released "as a measure to avoid flooding the entire Bertam Valley", following heavy rains and flash flooding that "caused an overflow into Lake Ringlet that surpassed maximum levels". Local sources reported that one of the dam's four gates was opened to help lower the water level, and that if it had not been opened, all four dam gates might have opened automatically which potential to cause even more damage (Hydroworld.com, 2013). The dam maintenance is another challenge for the dam due to the huge sheer size and volume, underwater maintenance of tunnels, intake structures and the reservoir, completely shut down for 80-90 days is required for the turbines maintenance service to take place every 10-15 years (Sovacool and Bulan, 2011). With the high rainfall around the reservoir makes the service maintenance work difficult to be carried out.

\section{Economical aspects}

\section{Future water demand}

The population of Malaysia is continuing to grow where the population of Peninsular Malaysia will double its size from 18.1 million in 2000 to 38 million in 2050. The future water demand is depending on the population growth and socio-economic development. Urbanization and migration from rural to urban area is also evident where a relative number of the population concentrated in urban areas where high economic activities exist. The increasing population associated with the increasing economic development gives improvements in the standard of living results in the increased demand for water supply. Thus, it has given a pressure on the water resources. The challenge is not only to provide adequate water for the increasing demand but also stimulate the development in rural areas to relieve migration and reduce the pressure in the urban areas. The domestic and industrial water demand for Peninsular Malaysia is projected to increase 3-fold from $9543 \mathrm{MLD}$ (3483 million $\mathrm{m}^{3} / \mathrm{yr}$ ) in 2000 to 31,628 MLD (11,543 million $\left.\mathrm{m}^{3} / \mathrm{yr}\right)$ in 2050. On a Peninsular Malaysia-wide basis, during periods of severe drought, the average natural or unregulated flows can barely meet the projected demand in 2050 of 31,628 MLD. Therefore, new dams or water reservoirs are needed as new sources to augment water supply over the next 50 years (Mohamad Salleh, 2011). 


\section{Capital intensity, financing and returns on investment}

Constructing a dam is a huge investment in the water infrastructure and its affiliated infrastructure. Financing remains a big challenge relating to where the money will come to meet the project plan. Building a dam is normally financed by public borrowing. Any cost overruns in building a dam can increase the stock of debt. The recurring financing cost can further escalate if interest rates go up. For example, the actual cost of Pakistan's Tarbela dam, the majority of which was borrowed from external sources, amounted to $23 \%$ of the increase in Pakistan's external public debt stock between 1968 and 1984 (Flyvbjerg et al., 2014). In addition, the cost analysis of the dam construction often omits the effects of inflation and the risks of unanticipated inflation which resulting financed with additional debt. For example, the hyperinflation in Argentina, Brazil, Turkey and Yugoslavia caused staggering nominal cost overruns, e.g. 7-times initial budget for Brazil's Estreito dam (1965-1974), or 110-times initial budget for Yugoslavia's Visegrad dam (1985-1990). Also, the effects of unanticipated inflation exacerbate when the dam takes longer than planned time to complete a project. For example, during the planning stage of Pakistan's Tarbela dam, it was assumed that inflation would not have a significant impact on the project's costs. A general contingency of $7.5 \%$ has been added in accordance with normal practice for the project of this size and duration. However, the project which was launched in 1968, was meant to commence in 1976, but the opening was delayed until 1984. Such a delay has caused the actual cost of the dam in nominal terms nearly four times the initial budget due to the actual cumulative inflation in Pakistan during 1968-1984 was 380\%. It is about 8 out of 10 large dams delay of 2.3 years in completion whereby the expected annual inflation rate to be $2.5 \%$ but it turned out to be $18.9 \%$. Large dams particularly have a high tendency to face unanticipated inflation. Thus, the outsides view suggests that in most cases dam will be too challenging in absolute terms and take too long time to build and deliver a positive return on investment (Flyvbjerg et al., 2014).

\section{Social aspects}

\section{Community relocation, resettlement and compensation}

The construction of dams often, if not always, involves relocation of communities and livelihoods. When relocation and resettlement take place, compensation is recognized as providing support to displaced people and to the maintenance of the legitimacy of socio-political structures and the modernization project (Wang et al., 2013). Affected community have to make the difficult decision of abandoning their homes and livelihoods, causing emotional distress. Therefore, adequate compensation is needed to compensate their loss of natural resources, social heritage and land which cause misery to their distressed livelihood. Without adequate compensation, resettlement of people into a new area will not improve the lives of the community and this has failed to accomplish the purpose of resettlement (Sovacool and Bulan, 2011). Thus, the relocation, resettlement and compensation of the community are of the most challenging social barrier to be taken into account prior to the construction of dam.

\section{Community livelihood and welfare}

Social impacts on community livelihood and welfare caused by the relocation and resettlement are diverse. For example, the relocation of residents due to Manwan Dam 
China has caused the diversified income sources, widened income gaps and gave an overall adverse impact on standard of living ( $\mathrm{Fu}$ and $\mathrm{He}, 2003$ ). Also, the displacement of the entire indigenous population (around 10,000 people) in Bakun dam region has caused a drastic process of socio-economic disintegration and cultural extinction of the indigenous communities. Such a displacement has also caused the abandonment of traditional livelihood and economic activities which were adapted to local ecosystem and the complete loss of knowledge of these practices within the local population (Choy, 2005). It is also argued that the construction of Three Gorges Dam has impacted the cultural heritage whereby it has eradicated some historical heritage sites and unique sources of knowledge due to dam inundation (Jackson and Sleigh, 2000).

\section{Environmental aspects}

\section{Climate change}

The future climate change is going to impact the hydrological regime and water resources in Malaysia (Wong et al., 2009). Table 11 shows the projected rainfall for 2025-2050 for Malaysia. This hydroclimate projection study shows a projection increase in average annual precipitation $(\mathrm{mm})$ in Perak, Kedah, Terengganu, Kelantan and Pahang. However, a decrease in average annual precipitation $(\mathrm{mm})$ is projected in developed urban areas like Klang, Selangor and Johor (Kavvas et al., 2007). Higher maximum and lower minimum rainfall observed could result in more extreme hydrological conditions. These changes in rainfall have led to changes in the river flows. The flood flow changes range from $+6 \%$ to $+47 \%$, while the low flow changes range from $-35 \%$ to $-93 \%$, in which more frequent floods and droughts are projected in future (Zakaria and Shaaban, 2007). Climate change is a challenging factor in the planning and constructing of a multi-purpose dam in a tropical country like Malaysia as the dynamic condition of the local region could change the climatic condition as well as the level of hydrological regime.

Table 11. Average annual rainfall (Kavvas et al., 2007)

\begin{tabular}{c|c|c|c|c}
\hline \multirow{2}{*}{ Regions } & \multirow{2}{*}{ Sub regions } & \multicolumn{3}{|c}{ Average annual precipitation (mm) } \\
\cline { 3 - 5 } & & $\mathbf{1 9 8 4 - 1 9 9 3}(\mathbf{1})$ & $\mathbf{2 0 4 1 - 2 0 5 0}(\mathbf{2})$ & $\mathbf{( 2 ) - ( 1 )}$ \\
\hline \multirow{4}{*}{ North West Region } & West Coast & 2151.0 & 2099.3 & -51.7 \\
& Perak & 2314.8 & 2398.0 & 83.1 \\
& Kedah & 2082.9 & 2163.0 & 80.1 \\
\hline \multirow{3}{*}{ North East Region } & Northeast Cost & 3114.3 & 3292.2 & 177.8 \\
& Terengganu & 3467.8 & 3497.4 & 29.5 \\
& Kelantan & 2661.8 & 2865.0 & 203.2 \\
\hline \multirow{3}{*}{ Central Region } & Klang & 2281.5 & 2158.9 & -122.6 \\
& Selangor & 2282.3 & 2176.9 & -105.4 \\
& Pahang & 2381.8 & 2523.1 & 141.3 \\
\hline \multirow{2}{*}{ Southern Region } & Johor & 2247.8 & 2139.4 & -108.4 \\
& Southern Peninsular & 2324.5 & 2298.4 & -26.1 \\
\hline
\end{tabular}




\section{Land clearing, deforestation, degradation, impoundment and greenhouse gas emission}

The most significant environmental challenge is the land clearing, deforestation, land degradation, impoundment of reservoir and greenhouse gas emission (Sovacool and Bulan, 2011). A huge area of bare land is needed for water impoundment. Therefore, extensive logging is the only way to acquire land within the catchment area. It is noted by Choy (2005) that the deforestation and submerging of the catchment area will destroy biomass home to rare and endangered species, protected bird species, protected mammals, protected plants including herons, eagles, woodpeckers, silvered leaf monkeys, Bornean gibbons, langurs, and flying squirrels. To accelerate the logging process, access roads is built to the dam and further worsen the deforestation and lead to the degradation of the exposed bare land. It is also noted that impoundment process during the dam construction will become a significant source of greenhouse gas emissions, especially carbon dioxide and methane arising from microbial decomposition of the submerged forest, vegetation, wildlife and soil. Figure 4 shows microbial and methanogenesis and denitrification of impoundment process. The inundated forest biomass will be transformed into carbon dioxide $\left(\mathrm{CO}_{2}\right)$ and methane $\left(\mathrm{CH}_{4}\right)$ and nitrous oxide $\left(\mathrm{N}_{3} \mathrm{O}\right)$ through decomposition, microbial methanogenesis and denitrification. The anoxic condition in the deep reservoir will trigger the conversion of organic carbon into $\mathrm{CH}_{4}$ instead of $\mathrm{CO}_{2} . \mathrm{CH}_{4}$ in shallow waters may form bubbles and release to the atmosphere. The emission of these greenhouse gases may be built up in the atmosphere as a heat trapping layer. Carbon emission is primarily contributed by the flooded biomass. Other sources of carbon emission include (i) carbon from the soil and peat of the reservoir; (ii) dissolved organic carbon/particulate organic carbon; (iii) organic debris from the catchment and; (iv) decomposition of animals and algae in the reservoir following their death.

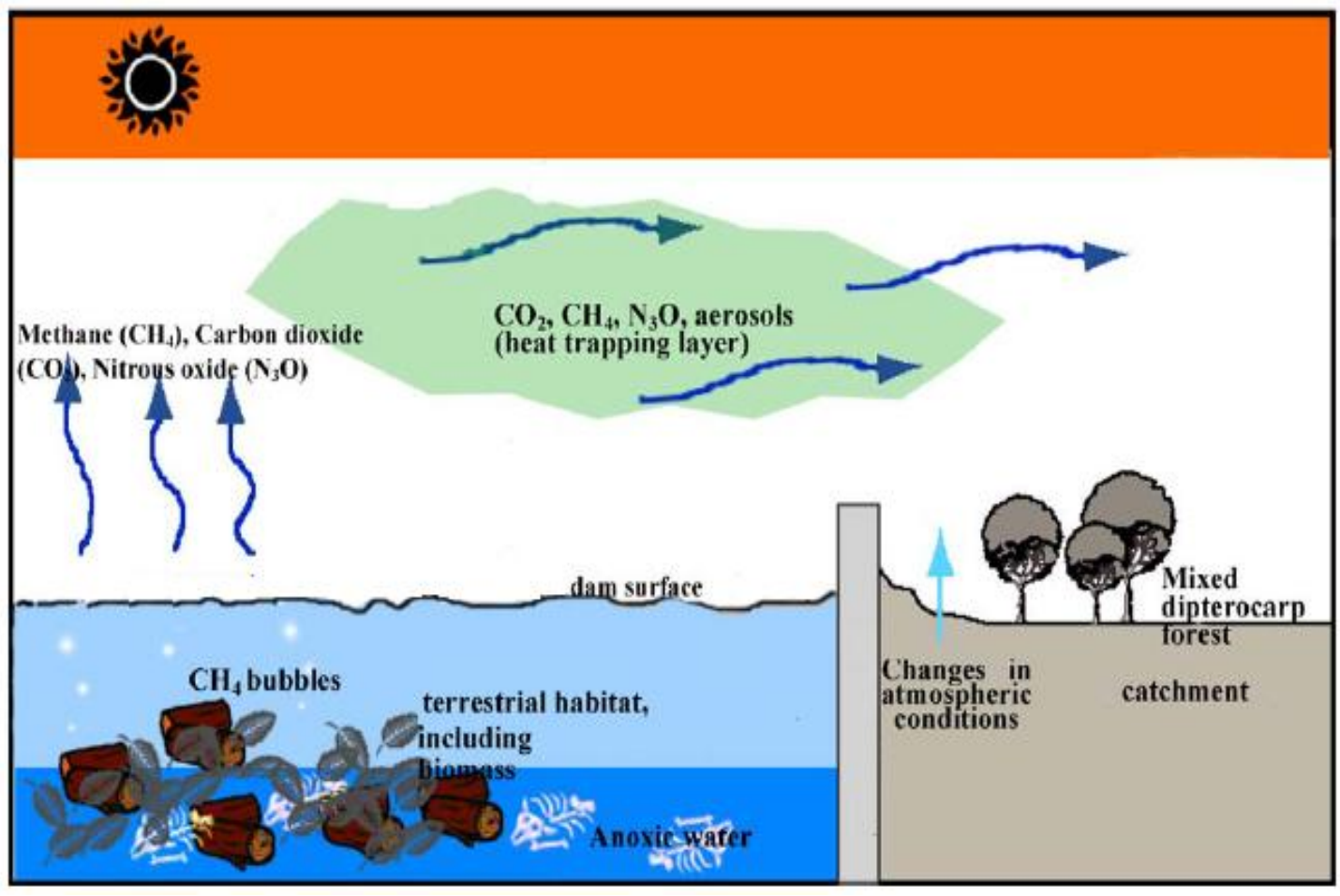

Figure 4. Microbial methanogenesis and denitrification of the impoundment process (Choy, 2005) 
The warming effect is also associated with greenhouse gas emission when the extra energy attempts to leave the earth surface in the form of infrared radiation, but much of it will be absorbed in the atmosphere by the principal heat-trapping gases such as water vapour, $\mathrm{CO}_{2}$ and $\mathrm{CH}_{4}$. This turn of event will not only contribute to global warming, but also affects the sink capacity for atmospheric pollution and hydrological conditions in the surrounding area of dam. This sequence of climatic change will pose a severe ecological threat on forest ecosystem in the catchment area. As illustrated by Choy (2005) in Figure 5, the microclimate change in the surrounding area of dam is mainly attributed to the complete exposure of the dam surface to direct solar irradiance. Some of the heat is reflected to the space immediately from the top of the clouds (17\%) while adsorbing about $4 \%$ of it. The rest is absorbed by the atmosphere $(23 \%)$ or the surface (46\%). Respectively, the aerosols and terrestrial surface reflect about $8 \%$ and $6 \%$ of the incoming radiation in the form of infrared radiation but much of it is trapped in the atmosphere by the heat trapping gases $\left(\mathrm{CO}_{2}, \mathrm{CH}_{4}, \mathrm{~N}_{2} \mathrm{O}\right.$, and water vapour). This serves to worsen the warming effect.

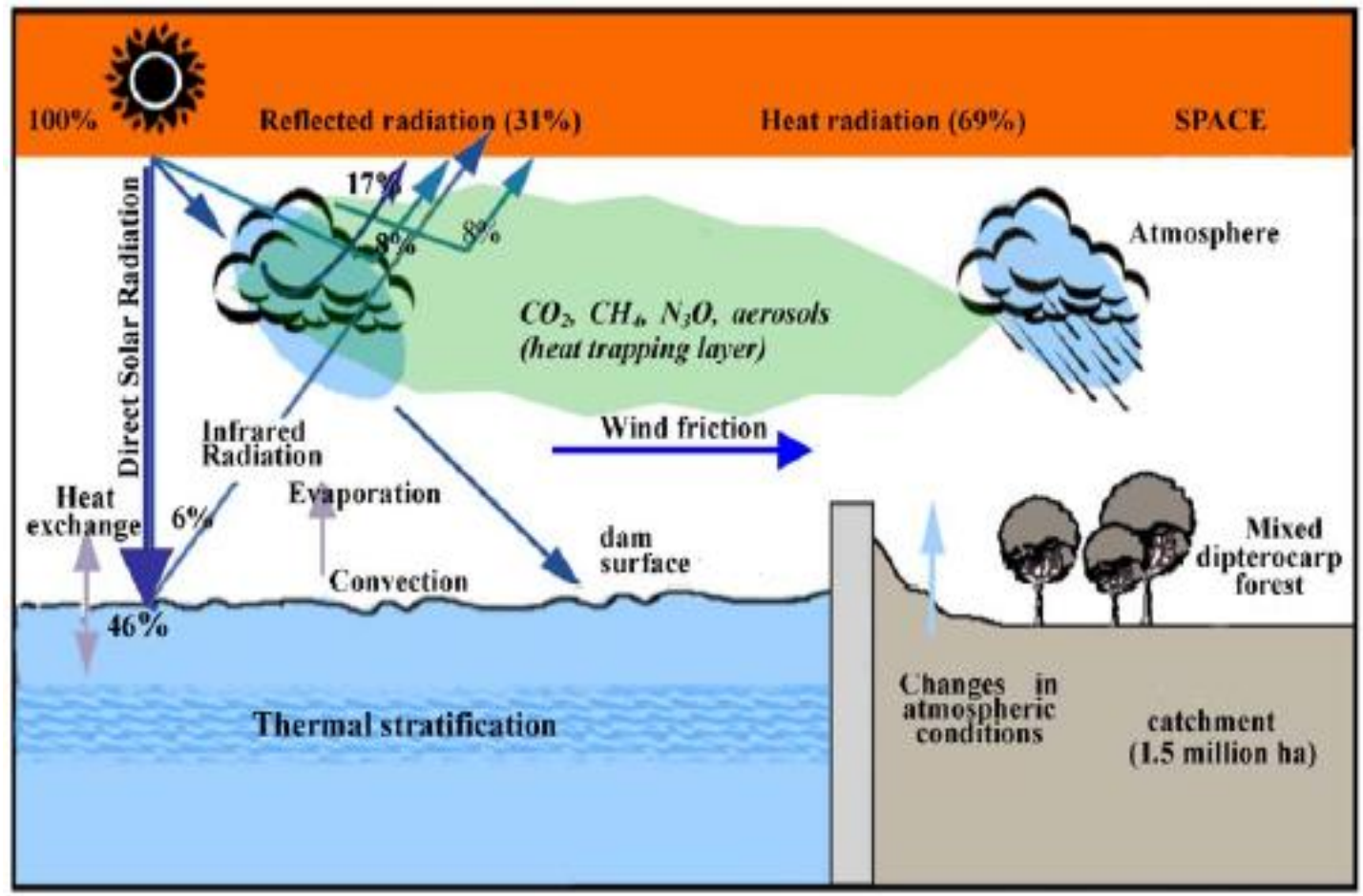

Figure 5. Warming effect and seasonal microclimate change at the surrounding area of dam

(Choy, 2005)

\section{Changes to water quality and river flow}

Another environmental challenge is noted by Sovacool and Bulan (2011) where the construction, impoundment and operation of dam will also affect the water quality, hydrology as well as river flow. The development project will negatively influence the water quality of the catchment area through changes in the concentration of dissolved oxygen, nutrient loads, suspended sediments, and that tidal encroachment could aggravate bank erosion. During the land clearing and construction stage, due to the extensive logging and construction activities, the water body of catchment is affected by 
the increased turbidity, loss of pool nursery habitat, reduced organic input and impaired the migration of fish. The environment would be further impacted during impoundment where river flow and organic input will be reduced and resulting in loss of habitat due to reduced water depth. The impoundment also results in increased phytoplankton production. Fish migration will be impaired due to the replacement of natural riverine habitat with artificial deep lake habitat. During the operation of the dam, the rapid water fluctuations resulting from the operation of the spillway would also increase downstream riverbank erosion, wash away trees, and prevent the spawning of fish. It would negatively influence the population of freshwater fish which become easily disoriented in slow moving waters, and fish living near the dam would be susceptible to pulverization from passing through the turbines or super-saturation and excess nitrogen from the water around the concrete face. It would also alter upstream species composition and replace native riverine species with lake-adapted species in reservoir.

\section{Concluding remarks}

Water security has become a serious issue due to rapid population growth, unsustainable use, water degradation and climate change. Sustainable water resources management and development is needed to overcome the water security issue. Therefore, multi-purpose dam has been proposed to provide affordable water and energy for agriculture, industrial and domestic sectors and ensure essential irrigation water supplies for food security. No doubt that water resources are necessary for sustainable economic development of a country. However, building a dam should not primarily be considered as an economic decision, which ascertains that the total benefit obtained from the dam operation exceeds the total cost incurred by building and maintaining the dam. Dam has to be understood as an anthropogenic interference at a central position of a complex natural system, having multiple impacts, mainly on the downstream drainage basin. Having only proper development of multi-purpose dam for management of river waters can improve economic viability, preserve ecosystem and enhance social justice of the country in the coming years.

Acknowledgements. The authors would like to acknowledge the financial support for this study provided by Universiti Kebangsaan Malaysia through Arus Perdana (AP-2015-012) and Geran Universiti Penyelidikan (GUP-2017-016).

\section{REFERENCES}

[1] Azhar, G. M. (2000): Managing Malaysian water resources management. - Buletin Kesihatan Masyarakat Isu Khas 6: 40-58.

[2] Bedi, R. S., Avineshwaran, T. (2013): Protecting our water resources. http://www.thestar.com.my/News/Nation/2013/09/08/Protecting-our-water-resources/ (accessed 7 Jan 2015).

[3] BERNAMA (2012): Water. A resource that is crucial for survival. http://www.span.gov.my/index.php?option=com_content\&view=article\&id=503\%3Awat er-a-resource-that-is-crucial-for-survival\&lang=en (accessed 7 Jan 2015).

[4] Chan, N. W., Abdullah, A. L., Ibrahim, A. L., Ghazali, S. (2003): River pollution and restoration towards sustainable water resources management in Malaysia. - National 
Seminar on Society, Space and Environment in a Globalised World: Prospects \& Challenges, Penang.

[5] Choy, Y. K. (2005): Energy demand, economic growth, and energy efficiency - the Bakun dam-induced sustainable energy policy revisited. - Energy Policy 33: 679-689.

[6] CIDB (2008): Compilation of Environmental Acts, Laws and Regulations Related to Construction Industry. - Perpustakaan Negara Malaysia, Kuala Lumpur.

[7] Cosgrove, W. J., Rijsberman, F. R. (2000): World Water Vision. - Earthscan Publications Ltd, London.

[8] DID (2009): DID Manual Volume 9 - Dam safety, inspections and monitoring. http://forum.mygeoportal.gov.my/smanre/aduan/Volume\%209_Dam\%20 Safety.pdf (accessed 7 Jan 2015).

[9] Flyvbjerg, A. B., Budzier, A., Lunn, D. (2014): Should we build more large dams? The actual cost of hydropower megaproject development. - Energy Policy 69: 43-56.

[10] Fu, B., He, Y. (2003): The effect on the emigration's income and reservoir area ecologycaused by farmland change in reservoir area of Manwan hydropower station. Territory \& Natural Resources Study 4: 45-46 (in Chinese).

[11] Hydroworld.com (2013): Dam release causes flooding in Malaysia. http://www.hydroworld.com/articles/2013/10/dam-release-causes-flooding-inmalaysia.html (accessed 7 Jan 2015).

[12] ICOLD (2014): Purposes of dams. - http://www.icoldcigb.org/GB/World_register/general_synthesis.asp (accessed 7 Jan 2015).

[13] Jackson, S., Sleigh, A. (2000): Resettlement for China's Three Gorges Dam: socioeconomic impact and institutional tensions. - Communist and Post-Communist Studies 33: 223-241.

[14] Kavvas, M. L., Chen, Z. Q., Ohara, N., Shaaban, A. J., Amin, M. Z. M. (2007): Impact of climate change on the hydrology and water resources of Peninsular Malaysia. Proceedings of International Congress on River Basin Management, Antalya, Turkey, pp. 528-537.

[15] Ministry of Land, Transport and Maritime Affairs Korea (2009): Act on Dam Construction and Assistance, Etc. to Neighbourhood Area. http://www.moleg.go.kr/english/korLawEng?pstSeq=52723 (accessed 7 Jan 2015).

[16] Ministry of Strategy and Finance, Republic of Korea (2013): 2012 Modularization of Korea's Development Experience: Korea's River Basin Management Policy. Knowledge Sharing Program Development Research and Learning Network, Seoul.

[17] Mohamad Salleh, H. (2011): Meeting water demand for industrialising Malaysia. http://www.jba.gov.my/files/Microsoft\%20Word\%20-

\%20MEETING\%20WATER\%20DEMAND\%20fOR\%20INDUSTRISATION\%20MAL YS.pdf (accessed 7 Jan 2015).

[18] Moon, Y. I., Kwon, H. H. (2003): Nonparametric Dam Risk Analysis for Dam Rehabilitation in South Korea. - In: Llanos, J. A., Yague, J., Sanz de Ormijana, F., Cabrera, M., Penas, J. (eds.) Dam Maintenance and Rehabilitation. Proceedings of the International Congress on Conservation and Rehabilitation of Dams. CRC Press, Netherlands.

[19] Musiake, K., Koike, T. (2009): Time for a change in Japanese water resources policy, part 1: Historical review of water resources management policy and challenges for the future. - International Journal of Water Resources Development 25: 555-564.

[20] Othman, Z. A. (2006): Overview of Dam Safety in Malaysia. http://dspace.unimap.edu.my/dspace/bitstream/123456789/13887/1/022023_overview\%2 0of\%20dam.pdf (accessed 7 Jan 2015).

[21] PAAB (2013): National water services industry restructuring initiatives. http://www.paab.my/reform-in-water-services-industry/national-water-services-industryrestructuring-initiatives (accessed 7 Jan 2015). 
[22] Petersson, E., Ostrowski, M. W. (2003): Large dams - a contribution to sustainable water and energy development. - In: Bloschl, G., Franks, S., Kumagai, M., Musiake, K., Rosbjerg, D. (eds.) Water Resources Systems - Hydrological Risk, Management and Development. Proceedings of the Symposium HS02b. IAHS Press, UK.

[23] Raja Zainal Abidin, R. D. Z. (2004): Water Resources Management in Malaysia - The Way Forward. - Asia Water 2004, Kuala Lumpur.

[24] Salleh, H. M. (2011): Meeting water demand for industrialising Malaysia. -Jabatan Bekalan Air, Kementerian Tenaga, Teknologi Hijau dan Air, Malaysia. http://www.jba.gov.my/images/JBA/Rujukan/KertasKerja/35_MEETING_WATER_DE MAND_fOR_INDUSTRISATION_MALYS.pdf (accessed 26 Feb 2018).

[25] Sovacool, B. K., Bulan, L. C. (2011): Behind an ambitious megaprojects in Asia: The history and implications of the Bakun hydroelectric dam in Borneo. - Energy Policy 39: 4842-4859.

[26] Sovacool, B. K., Bulan, L. C. (2012): Energy security and hydropower development in Malaysia: The drivers and challenges facing the Sarawak Corridor of Renewable Energy (SCORE). - Renew Energy 40: 113-129.

[27] SPAN (2012): Media statement - Reducing NRW level in Malaysia. http://www.span.gov.my/index.php?option=com_content\&view=article\&id=431\%3Ame dia-statement-reducing-nrw-level-in-malaysia\&lang=en (accessed 7 Jan 2015).

[28] Wahab, N. A. A. (2011): Overview of the water services industry in Malaysia. http://www.mlit.go.jp/common/000135515.pdf (accessed 7 Jan 2015).

[29] Wang, P., Wolf, S. A., Lassoie, J. P., Dong, S. (2013): Compensation policy for displacement caused by dam construction in China: An institutional analysis. - Geoforum 48: $1-9$.

[30] WEPA (2006): State of water environmental issues. - http://www.wepadb.net/policies/state/malaysia/river.htm (accessed 7 Jan 2015).

[31] Wong, C. L., Venneker, R., Uhlenbrook, S., Jamil, A. B. M., Zhou, Y. (2009): Variability of rainfall in Peninsular Malaysia. - Hydrology and Earth System Sciences Discussions 6: 5471-5503.

[32] Zakaria, S., Shaaban, H. A. J. (2007): Impact of Climate Change on Malaysia Water Resources. - National Hydraulic Research Institute of Malaysia (NAHRIM), Ministry of Natural Resources and Environment (NRE), Malaysia.

[33] Zhou, Y., Guo, S. (2013): Incorporating ecological requirement into multipurpose reservoir operating rule curves for adaptation to climate change. - Journal of Hydrology 298: 153-164. 